\title{
PENYUSUNAN BATTERY TEST OLAHRAGA BOLA VOLI
}

\author{
Furkan \& Shutan Arie Shandi \\ Dosen Prodi PJKR STKIP Taman Siswa Bima \\ furkanmaster007@gmail.com
}

abstrak

Penelitian ini bertujuan untuk menyusun sebuah tes keterampilan untuk cabang olahraga bola voli. Tes keterampilan terdiri dari tes individu dan kelompok. Tes keterampilan individu meliputi tes ketepatan dan kinerja, sedangkan tes keterampilan kelompok yaitu tes keberhasilan dan bermain. Penelitian ini merupakan penelitian survei. Populasi yang digunakan adalah atlet yang tergabung di klub bolavoli STKIP Taman Siswa Bima. Sampel dipilih secara purposive dengan ciri-ciri atlet, berjenis kelamin laki-laki, aktif berlatih, dan bersedia menjadi sampel. Hasil penelitian adalah terciptanya battery test dan petunjuk pelaksanaan untuk cabang olahraga bola voli. Battery test pada teknik servis dengan validitas 0.625 dan reliabiltas 0.768 , pas bawah dengan validitas 0.643 dan reliabilitas 0.780 , pas atas dengan validitas 0.684 dan reliabilitas 0.807 , teknik memukul/smes dengan validitas 0.635 dan reliabilitas 0.756 , dan teknik bendungan/blok dengan validitas 0.867 dan reliabilitas 0.920 . Dengan adanya battery test dapat dimanfaatkan oleh pelatih, manajer dan official tim dalam rangka untuk memilih pemain, maka dapat diharapkan prestasi olahraga bola voli akan optimal.

Kata kunci: battery test, bola voli

\section{PENDAHULUAN}

Olahraga merupakan suatu aktivitas yang dilakukan oleh manusia baik muda maupun tua dengan maksud untuk memenuhi kebutuhan hidup. Kebutuhan hidup yang diharapkan dari aktivitas olahraga adalah kesehatan atau kebugaran yang berhubungan dengan jasmani dan rokhani. Aktivitas olahraga sekarang dalam perkembangan tidak hanya untuk kesehatan atau kebugaran, tetapi juga untuk rekreasi dan prestasi. Aktivitas olahraga dapat dilakukan atau dilaksanakan dengan berbagai bentuk atau cabang olahraga. Cabang olahraga dalam melakukan aktivitasnya dapat dibedakan menurut bola yang digunakan, yaitu olahraga bola kecil dan olahraga bola besar. Olahraga bola kecil, misalnya tenis lapangan, tenis meja, softball, baseball, sedangkan olahraga bola besar, misalnya sepakbola, bolabasket dan bola voli.

Olahraga bola voli diciptakan oleh Guru pendidikan jasmani pada Young Men Christian Association (YMCA) yang bernama William G. Morgan pada tahun 1895. Pada awalnya olahraga bola voli bertujuan untuk rekreasi para karyawan di suatu perusahaan. Aktivitas olahraga bola voli dengan bola yang lebih ringan dan lembut serta tidak adanya kontak fisik di antara olahragawan. Olahraga bola voli dalam perkembangan sekarang tidak hanya bertujuan rekreasi, tetapi bertujuan untuk prestasi. Olahraga bola voli dapat dimainkan oleh anak muda dan orang tua dengan aman pada saat tertentu baik di kantor atau perusahaan.

Pada mulanya olahraga bola voli yang berkembang di Amerika, dinamakan minnonette oleh William G. Morgan. Olahraga minnonette sebagai perkembangan dari olahraga bola basket yang diciptakan oleh James A. Naismith. Olahraga bola basket yang dianggap oleh William G. Morgan terlalu berat dalam melakukan aktivitas, terutama berat bola, besar/ukuran bolanya, dan adanya kontak badan antar olahragawan. Olahraga bola basket sudah tidak nyaman lagi bila digunakan sebagai aktivitas orang dewasa yang usianya lanjut. Oleh karena itu William G. Morgan sebagai guru pendidikan jasmani pada YMCA (Young Men Christian 
Association) dan konsultan suatu perusahaan ingin memberikan suatu aktivitas olahraga yang dapat digunakan untuk para pekerja perusahaan yang bertujuan untuk rekreasi dan meningkatkan kebugaran jasmani. William G. Morgan menciptakan suatu aktivitas olahraga yang diberi nama minnonette, di mana permainan ini sifatnya sebagai kegiatan/aktivitas untuk rekreasi. Olahraga yang diberi nama minnonette pada awal permainannya, untuk pertama kali, sentuhan bola bebas asalkan selalu memantulkan/volley bola, jumlah pemain bebas, ukuran lapangan tidak ditentukan dan bola yang digunakan adalah bagian dalam bola basket yang dibatasi suatu pemisah berupa tali setinggi 2 meter.

Pada tahun 1896 oleh Dr. Halstead dari Springfield, Massachusetts, Amerika Serikat dengan melihat cara memainkan bola pada olahraga minnonette di mana prinsip dan cara memainkan bola selalu mem "volley" (memantulkan) bola dan bolanya tidak diperbolehkan menyentuhkan tanah. Pemberian nama olahraga volleyball (bola voli) oleh Dr. Halstead dikarenakan dari prinsip atau cara permainanya dengan mem"volley" (memantulkan) bola melintasi net secara berganti-ganti dan berulang-ulang. Dengan kesungguhan dan berkat kegigihan William G. Morgan dengan YMCA, olahraga bolavoli di Amerika Serikat dapat berkembang pesat. Perkembangan yang sangat pesat pada olahraga bola voli di negara-negara yang pernah diduduki oleh tentara Sekutu atau Amerika, karena di waktu luang banyak tentara Amerika melakukan olahraga bola voli di asrama/camp, secara tidak langsung sudah memperkenalkan olahraga bola voli pada masyarakat di sekitarnya. Olahraga bola voli sudah populer di berbagai negara, hal ini dapat dilihat dari banyaknya negara sebagai anggota Federation Interntional Vollyball (FIVB) dan masyarakat yang berpartisipasi dalam olahraga bola voli. Perkembangan olahraga bola voli di Indonesia sejak adanya penjajahan Belanda, di mana banyak tentara Belanda melakukan aktivitas olahraga bola voli di barak/camp pada waktu luang.
Perkembangan olahraga bola voli sekarang ini sudah sampai pada daerah-daerah pantai, terutama pantai yang dapat dipergunakan untuk kegiatan pariwisata. Di daerah pantai sudah banyak fasilitas lapangan olahraga bola voli yang dapat digunakan untuk olahraga bola voli pantai. Pada musim panas sering diadakan suatu pertandingan olahraga bola voli pantai dengan tujuan untuk meramaikan kegiatan pariwisata di pantai dengan harapan akan banyak dihadiri oleh para wisatawan domestik maupun luar negeri.

Olahraga bola voli dalam permainannya dimulai dengan melakukan servis (service) yang dilaksanakan dengan pukulan satu tangan dan bola melewati net, selanjutnya setiap regu sesuai dengan peraturan permainan olahraga bola voli mempunyai hak memainkan bola sebanyak tiga kali sebelum diseberangkan ke seberang net, tetapi regu tersebut juga diperbolehkan memainkan bola sekali atau dua kali. Sebelum bola menyentuh lantai, menyentuh benda di luar lapangan, atau pemain melakukan kesalahan maka bola boleh dimainkan lagi. Secara peraturan permainan olahraga bola voli dimulai dari teknik serve diterima dengan teknik pas bawah (forearm pass) atau pas atas (overhead pass), lalu diumpankan dengan teknik pas atas (overhead pass) atau pas bawah (foream pass), lalu dipukul (tehnic spike), lalu dibendung (tehnic block), bila belum mati dimulai lagi dari teknik pas bawah (foream pass) atau pas atas (overhead pass), diumpankan dengan teknik pas atas (overhead pass) atau pas bawah (foream pass), lalu dipukul (spike) dan seterusnya, bila bola sudah mati, maka diulang dari servis lagi. Dengan demikian teknik dasar yang harus dimiliki oleh seorang pemain olahraga bola voli terdiri dari teknik servis (service), teknik pass bawah (forearm pass), teknik pas atas (overhead pass), teknik memukul (spike), teknik bendungan (block).

Pencapaian prestasi maksimal atau optimal dalam olahraga bola voli, diperlukan sebuah pembinaan olahragawan yang sangat panjang kurang lebih 
10-12 tahun. Sebagaimana dikemukakan oleh Bompa (1990: 31) bahwa prinsip pembinaan olahraga diawali dari tahap multilateral, tahap spesialisasi, tahap prestasi puncak. Tahap multilateral/pemula dengan cara memberikan penekanan latihan pada pengenalan berbagai cabang olahraga, tetapi untuk

olahraga bola voli dimulai usia 11-12 tahun. Tahap spesialisasi penekanan latihan pada pemilihan salah satu cabang tertentu yang benar-benar ditekuni dan mempunyai prospektif terhadap pencapaian prestasi maksimal, untuk olahraga bola voli pada usia 14-15 tahun. Tahap prestasi puncak di mana olahragawan berusaha untuk memelihara prestasi maksimal/optimal untuk jangka waktu yang lama, untuk olahraga bola voli pada usia 20-25 tahun.

Pencapaian prestasi olahraga bola voli secara maksimal/optimal sangat dipengaruhi oleh berbagai faktor yang ada, diantarannya peran dari para ahli, seperti pelatih, ahli gizi, dan beberapa ahli yang lain serta olahragawan itu sendiri. Peran pelatih cabang olahraga bola voli dapat dilihat pada saat proses berlatih melatih yang bertujuan untuk mencapai prestasi maksimal atau optimal. Pelatih olahraga bola voli dalam melakukan proses berlatih melatih, bertujuan untuk meningkatkan ranah/aspek kognitif, ranah/aspek psikomotor, dan ranah/aspek afektif olahragawan. Ranah /aspek kognitif merupakan kemampuan yang terkait dengan pengetahuan misalnya: peraturan pertandingan, teknik dan strategi yang berkembang, area lapangan olahraga bola voli. Ranah/aspek keterampilan merupakan kemampuan teknik yang harus dikuasai olahraga bola voli. Ranah/aspek afektif merupakan kemampuan untuk mengendalikan perilaku sebagai olahragawan, misalnya: sifat kejujuran, fairplay dalam pertandingan, menerima keputusan dari wasit dan sebagainya. Peningkatan tiga ranah/aspek tersebut sangat penting dalam menghadapi pertandingan olahraga bola voli dalam mencapai prestasi maksimal/optimal.
Ranah/aspek Psikomotor olahraga bola voli yang harus dikuasai terdiri dari teknik servis, pas bawah, pas atas, memukul, dan bendungan. Penguasaan keterampilan teknik sangat memerlukan komponen kondisi fisik dan mental. Olahragawan dalam mengikuti suatu kegiatan olahraga bola voli ada yang penguasaan teknik atau keterampilan sudah mahir dan ada yang keterampilannya sangat kurang mahir. Penguasaan keterampilan diperoleh dalam proses berlatih melatih, namun ada juga individu yang memiliki kemampuan kurang mahir dalam penguasaan keterampilan pada proses berlatih melatih. Olahragawan yang mengalami kesulitan/kurang mahir dalam mengikuti proses berlatih melatih olahraga bola voli, maka pelatih dapat membuat program latihan secara kelompok maupun individu untuk masing- masing olahragawan. Pelatih olahraga bola voli untuk melihat peningkatan prestasi olahragawannya dapat melakukan penilaian dengan memanfaatkan pengukuran keterampilan. Pengukuran keterampilan olahraga bola voli dapat dilakukan dengan pengukuran/penilaian ketepatan, kinerja, dan bermain.

Keterampilan teknik/taktik olahraga bola voli terdiri dari teknik individual dan taktik olahraga bola voli. Teknik individual olahraga bola voli yang meliputi teknik pertahanan individual (individual defence), teknik gerak tanpa bola (movement pattens), teknik servis (serving), teknik pas bawah (forearm pass), teknik pas atas (overhead pass), teknik memukul (spike), teknik bendungan (blocking). Taktik olahraga bola voli terdiri dari taktik pertahanan (defense) dan taktik penyerangan (offence). Konsep psiko-sosial

yang ada dalam olahraga bola voli adalah kerjasama yang harus dilakukan oleh tim atau regu, selain pembinaan mental untuk menjadi juara.

Dengan melihat pada uraian di atas mengenai perkembangan olahraga bola voli dari sisi teknik, taktik dan peraturan sangat pesat. Perkembangan olahraga bola voli 
mengenai pengukuran keterampilan sudah banyak dikembangkan, tetapi belum ada untuk olahraga bola voli yang bertujuan untuk prestasi. Pengukuran olahraga bola voli, oleh peneliti sangat diperlukan adanya penyusunan battery test, terutama untuk olahragawan pada tingkat yunior dan senior. Oleh karena itu peneliti ingin mencoba membuat battery test olahraga bola voli atlit Bolavoli STKIP Taman Siswa Bima.

\section{METODE PENELITIAN}

\section{A. Jenis atau Desain Penelitian}

Metode yang digunakan untuk melaksanakan penelitian ini adalah survei. Jenis penelitian yang digunakan adalah pengembangan model/battery test dalam olahraga bola voli. Model/battery test yang dikembangkan adalah dengan mengembangkan pada setiap teknik olahraga bola voli, yaitu teknik servis, pas bawah, pas atas, memukul (smes), dan bendungan (blok).

\section{B. Populasi dan Sampel Penelitian}

Populasi dalam penelitian ini adalah seluruh atlet bola voli STKIP Taman Siswa Bima, yang berjumlah 20 atlet. Teknik pengambilan sampel secara purposive sampling.

\section{Variabel Penelitian}

Variabel dalam penelitian ini adalah ketepatan teknik servis, teknik pas bawah, teknik pas atas, teknik memukul (smes), dan teknik bendungan (blok).

\section{Teknik dan Instrumen Pengumpulan Data}

\section{Teknik Pengumpulan Data}

Berdasarkan variabel yang diteliti, data yang dikumpulkan meliputi ketepatan teknik-teknik olahraga bola voli, meliputi: servis, pas bawah, pas atas, smes, dan blok. Data diperoleh melalui tes pengukuran ketepatan.

2. Instrumen Pengumpulan Data a. Sasaran Tes Ketepatan Teknik Servis

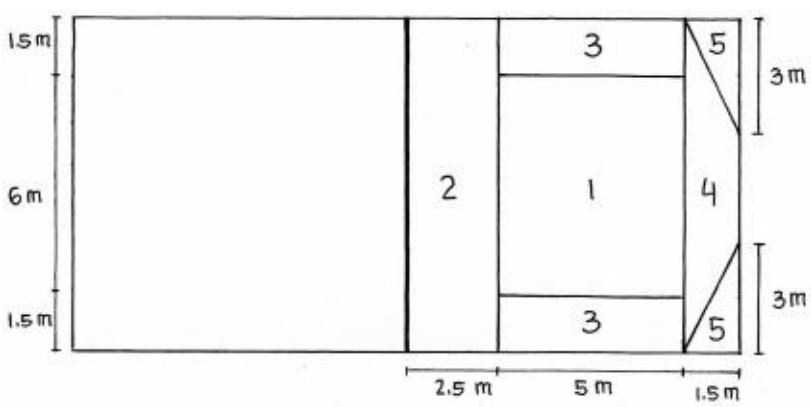

Pelaksanaan tes:

Atlet melakukan 10 kali servis atas, penilaian berdasarkan jatuhnya bola pada sasaran yang telah ditentukan.

\section{b. Sasaran Tes Ketepatan Teknik Pas Atas}

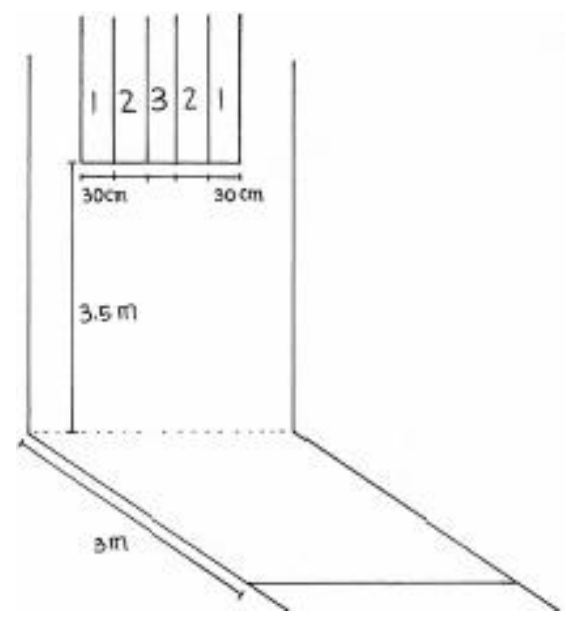

Pelaksanaan tes:

Atlet melakukan pas atas ke tembok selama 1 menit. Skor diberikan sesuai dengan sentuhan bola pada sasaran yang telah ditentukan.

\section{c. Sasaran Tes Ketepatan Teknik Pas Bawah}

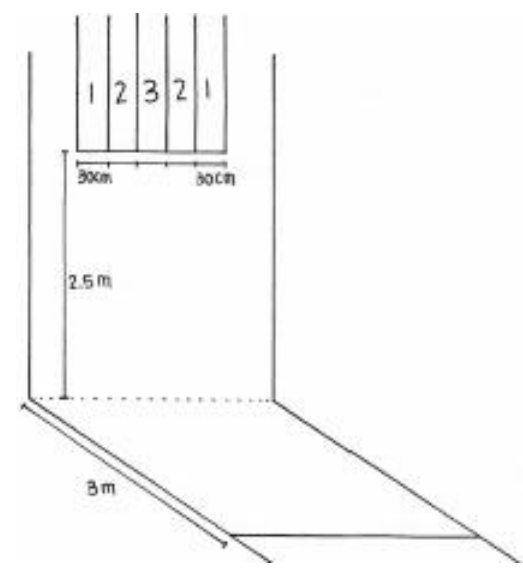

Pelaksanaan tes: 
JUPE: Jurnal Pendidikan Mandala

http://ejournal.mandalanursa.org/index.php/JUPE/index
Vol. 4. No. 5 Desember 2019

p-ISSN: 2548-5555 e-ISSN:2656-6745
Atlet melakukan pas bawah ke tembok selama 1 menit. Skor diberikan sesuai dengan sentuhan bola ke sasaran yang telah ditetapkan.

\section{d. Sasaran Tes Ketepatan Teknik Smes}

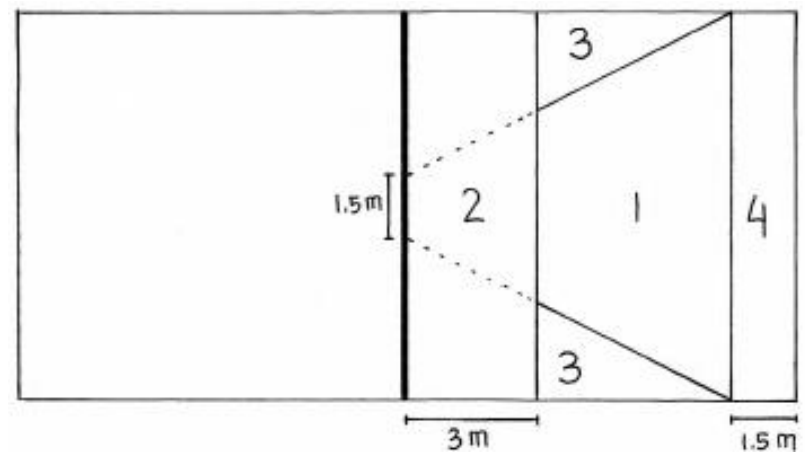

\section{Pelaksanaan tes:}

Atlet melakukan smes dengan cara melempar bola sendiri. Kesempatan yang diberikan 10 kali. Penilaian berdasarkan jatuhnya bola pada sasaran yang telah ditentukan.

\section{e. Sasaran Tes ketepatan Teknik Blok}

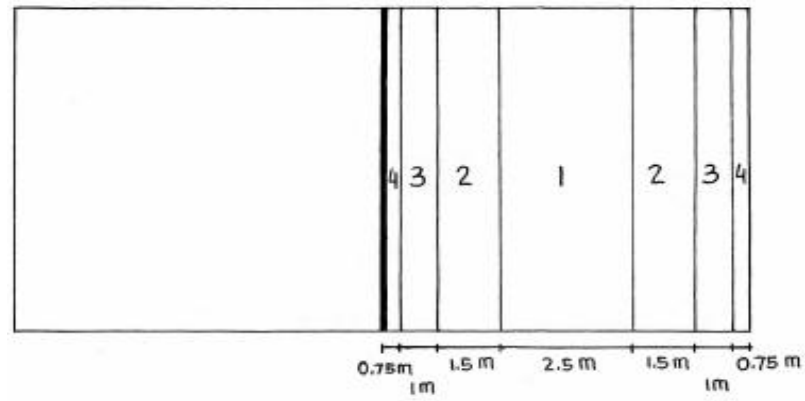

\section{Pelaksanaan tes:}

Atlet melakukan blok dengan cara melempar bola menyerupai blok. Kesempatan yang diberikan 10 kali. Skor diberikan sesuai dengan jatuhnya bola ke sasaran yang telah ditentukan.

\section{E. Teknik Analisis Data}

Teknik analisa data yang digunakan dalam penelitian ini adalah sebagai berikut: Uji validitas dan uji reliabilitas. Uji validitas yang digunakan adalah korelasi ProductMoment dari Karl Pearson. Uji reliabilitas menggunakan Scale Reliability Analysis dari Alpha Cronbach.

\section{HASIL PENELITIAN DAN PEMBAHASAN A. Hasil Penelitian \\ Penelitian ini dilaksanakan pada} tanggal 19 dan 20 Mei 2017 di lapangan bola voli STKIP Taman Siswa Bima. Sampel penelitian adalah atlet bolavoli putra STKIP Taman Siswa Bima. Hasil tes ketepatan yang telah dilakukan dalam penelitian ini adalah sebagai berikut:

\section{Tabel 1. Rekap Data Tes Ketepatan}

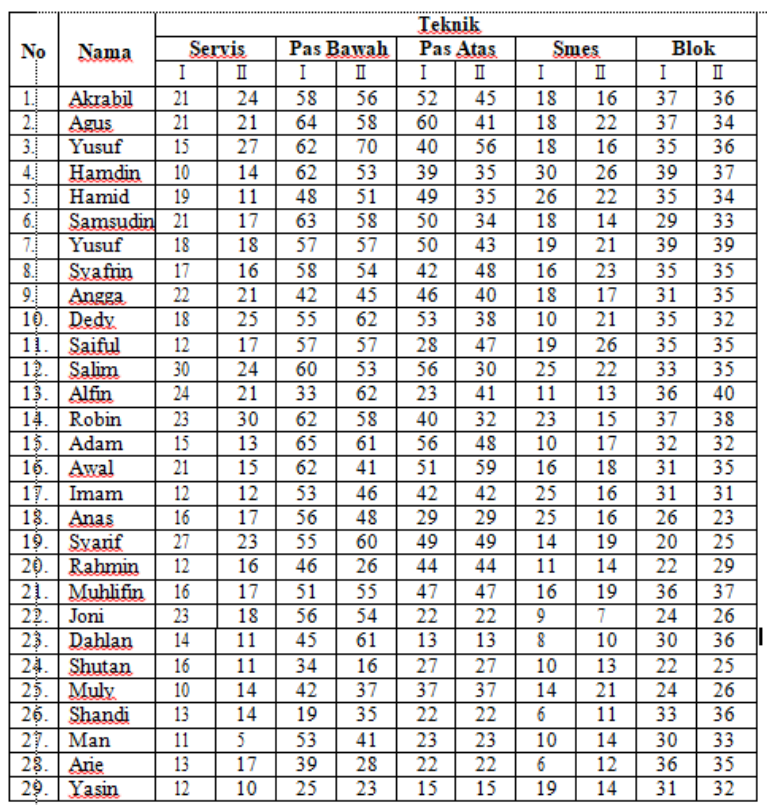

\section{B. Analisis Data Penelitian}

Setelah data terkumpul, dilakukan pengujian atau penghitungan. Dalam penelitian ini terdapat dua penghitungan, yaitu: (1) Validitas, dan (2) Reliabilitas.

\section{Penghitungan Validitas}

Dalam penelitian ini validitas dihitung menggunakan korelasi Product-Moment dari Karl Pearson. Menurut Sugiono (2007: 231) untuk menyatakan validitas instrumen, digunakan interpretasi terhadap koefisien korelasi sebagai berikut:

Tabel 2. Derajat Validitas dan Besarnya Koefisien Korelasi

\begin{tabular}{|c|c|}
\hline Derajat Validitas & Koefisien Korelasi \\
\hline Sangat Tinggi & $0.80-1.00$ \\
\hline Tinggi & $0.70-0.79$ \\
\hline Sedang & $0.50-0.69$ \\
\hline Rendah & $0.0-0.49$ \\
\hline
\end{tabular}

\section{Penghitungan Reliabilitas}


Penghitungan reliabilitas dalam penelitian ini menggunakan Scale Reliability Analysis dari Alpha Cronbach. Menurut Sugiono (2007: 231) untuk menyatakan reliabilitas instrumen, digunakan interpretasi statistik hitung sebagai berikut:

Tabel 3. Derajat Reliabilitas dan Besarnya Statistik Hitung

\begin{tabular}{|c|c|}
\hline Derajat Reliabilitas & Statistik Hitung \\
\hline Sangat Tinggi & $0.90-1.00$ \\
\hline Tinggi & $0.80-0.89$ \\
\hline Sedang & $0.60-0.79$ \\
\hline Rendah & $0.0-0.59$ \\
\hline
\end{tabular}

Hasil penghitungan validitas dan reliabilitas dalam penelitian ini sebagai berikut:

Tabel 4. Rangkuman Hasil Penghitungan Validitas dan Reliabilitas

\begin{tabular}{|c|c|c|c|}
\hline No & Item Teknik & Validita & Reliabilitas \\
\hline 1. & Servis & 0.625 & 0.768 \\
\hline 2. & Pas Bawah & 0.643 & 0.780 \\
\hline 3. & Pas Atas & 0.684 & 0.807 \\
\hline 4. & Smes & 0.635 & 0.756 \\
\hline 5. & Blok & 0.867 & 0.920 \\
\hline
\end{tabular}

Berdasarkan tabel 4 hasil analisis data penelitian sebagai berikut:

\section{a. Teknik Servis}

Dari hasil perhitungan, teknik servis mempunyai nilai validitas 0.625 dan nilai reliabilitas 0.768 .

\section{b. Teknik Pas Bawah}

Dari hasil perhitungan, teknik pas bawah mempunyai nilai validitas 0.643 dan nilai reliabilitas 0.780 .

\section{c. Teknik Pas Atas}

Dari hasil perhitungan, teknik pas atas mempunyai nilai validitas 0.684 dan nilai reliabilitas 0.807 .

\section{d. Teknik Smes}

Dari hasil perhitungan, teknik smes mempunyai nilai validitas 0.635 dan nilai reliabilitas 0.756 .

\section{e. Teknik Blok}

Dari hasil perhitungan, teknik blok mempunyai nilai validitas 0.867 dan nilai reliabilitas 0.920 .

\section{PEMBAHASAN}

\section{Teknik Servis}

Teknik servis mempunyai nilai validitas 0.625 dan nilai reliabilitas 0.768. Nilai validitas dan reliabilitas teknik servis tergolong dalam kategori sedang. Dalam pelaksanaan tes ketepatan teknik servis, testee dimungkinkan mengalami kesulitan untuk mengontrol laju bola agar tepat pada sasaran yang diinginkan. Di samping itu, testee mempunyai kecenderungan untuk memperoleh nilai tertinggi, sasaran tersebut berada di daerah lapangan belakang, hal ini banyak menyebabkan servis yang dilakukan jatuh di luar lapangan (out).

\section{Teknik Pas Bawah}

Teknik pas bawah mempunyai nilai validitas 0.643 dan nilai reliabilitas 0.780 . Nilai validitas dan reliabilitas teknik pas bawah tergolong dalam kategori sedang. Kurangnya konsentrasi dan kontrol dalam melakukan tes pas bawah menyebabkan bola luncas terlalu jauh, sehingga nilai skor yang diperoleh menjadi sedikit.

\section{Teknik Pas Atas}

Teknik pas atas mempunyai nilai validitas 0.684 dan reliabilitas 0.807. Nilai validitas teknik pas atas tergolong dalam kategori sedang dan nilai reliabilitasnya tergolong kategori tinggi. Apabila dibandingkan dengan tes pas bawah. Teknik pas atas lebih sedikit memerlukan koordinasi gerakan, sehingga frekuensi pantulan ke sasaran menjadi lebih banyak.

\section{Teknik Smes}

Teknik smes mempunyai nilai validitas 0.635 dan reliabilitas 0.756 . Nilai validitas dan reliabilitas teknik smes tergolong dalam kategori sedang. Dalam pelaksanaan tes ketepatan teknik smes, testee dipersilakan untuk melempar bola sendiri, sehingga tingkat kesulitan menjadi tinggi, apalagi harus melewati rintangan net dan tepat pada sasaran.

\section{Teknik Blok}

Teknik blok mempunyai nilai validitas 0.867 dan reliabilitas 0.920. Nilai validitas dan reliabilitas teknik blok tergolong dalam kategori sangat tinggi. Pelaksanaan tes ketepatan teknik blok, testee melakukan 
gerakan memantulkan bola melewati atas net menyerupai gerakan blok sesungguhnya. Dimungkinkan terlalu mudah untuk menempatkan bola ke sasaran, karena posisi bola dipegang sendiri.

\section{SIMPULAN}

Battery test olahraga bola voli tersusun dengan nilai validitas dan reliabilitas sebagai berikut:

1. Teknik Servis Nilai validitas 0.625 dan reliabilitas 0.768 .

2. Teknik Pas Bawah Nilai validitas 0.643 dan reliabilitas 0.780 .

3. Teknik Pas Atas Nilai validitas 0.684 dan reliabilitas 0.807

4. Teknik Smes Nilai validitas 0.635 dan reliabilitas 0.756 .

5. Teknik Blok Nilai validitas 0.867 dan reliabilitas 0.920 .

\section{Keterbatasan Penelitian}

Meskipun penelitian ini telah dilaksanakan dengan seksama dan berhasil menyusun battery test olahraga bola voli, namun hal ini tidak terlepas dari keterbatasan dan kelemahan. Kelemahan yang ada disebabkan oleh beberapa hal yaitu sebagai berikut:

1. Terbatasnya jumlah sampel penelitian dan faktor-faktor lain di luar kemampuan untuk mengatasi.

2. Tidak adanya pengelompokkan sampel berdasarkan tingkatan dalam olahraga bola voli.

\section{SARAN}

maka saran-saran yang dapat

dikemukakan adalah sebagai berikut:

1. Pada penelitian lanjut sebaiknya melibatkan sampel yang lebih besar.

2. Pada penelitian lanjut disarankan untuk lebih spesifik membedakan sampel atlet yang digunakan

\section{DAFTAR PUSTAKA}

Bompa, T. O. (1990). Theory and methodology of training, The Key to Athletic Performance ( $2^{\text {nd }}$ ed.). USA: Kendall/Hunt publishing Company.
Kenny, B. \& Gregory, C. (2006). Volleyball steps to success. United State of America: Human Kinetic. Inc.

Neville, W. J. (1990). Coaching volleyball successfully. Illinois United StateAmerica: Leisure Press Champaign.

Nicholls, K. (1973). Modern volleyball for teacher, coach and player. London : Henry Kimpton Publishers.

Sally Kus. (2004). Coaching volleyball successfully. United State America: Human Kinetics. 